\title{
COMMISSION 14: ATOMIC AND MOLECULAR DATA (DONNEES ATOMIQUES ET MOLECULAIRES)
}

\section{PRESIDENT: François Rostas}

\section{VICE-PRESIDENT: Peter L. Smith}

ORGANIZING COMMITTEE: K. A. Berrington, N. Feautrier, S. Johansson, U.G. Jørgensen, W. C. Martin, H. Mason, W. Parkinson, W.-Ü.L. TchangBrillet

\section{Business Meeting at IAU XXIVthe General Assembly}

Present:

S. Adelman, P. Bernath, K. Berrington, A. Dalgarno, S. Federman, W. Herbst, M. Huber, S. Johansson, F. Johnson, F. Launay, W. C. Martin, D. Morton, G. Peach, J. Pickering, F. Rostas, S. Saito, P. Smith, J. Tatum, W.-Ü. Tchang-Brillet

The meeting was called to order by Rostas. After an agenda was adopted, he gave his report as the outgoing President. He pointed out that Joint Discussion 1, which our Commission sponsored, had a minimum attendance of 80 people per session. The IAU Executive Committee was generous with grants for people attending this JD.

Rostas reported that the visibility of Proceedings of Joint Discussions was considered at the Commission Presidents' meeting. The Proceedings will be made larger in the Highlights. It was suggested that a new publication series be devoted to such Proceedings. Another suggestion involved replacing the Vice Presidents with the Division Presidents, but that creates a potential problem with National Representatives.

The Commission 14 members approved of putting its triennial report on the web site as it is a useful document that also provides visibility to the Commission. Abstracts of papers and news were suggested as additional content.

The new Organizing Committee was approved. Our Commission's usual practice is for a member to serve for six years. The new organizing committee follows:

$\begin{array}{ll}\text { President: } & \text { Peter SMITH, USA } \\ \text { Vice President: } & \text { Sveneric JOHANSSON, Sweden } \\ \text { Secretary: } & \text { Saul J. ADELMAN, USA }\end{array}$

Organizing Committee:

Members carried over:

Keith A. BERRINGTON, UK

Nicole FEAUTRIER, France

Sveneric JOHANSSON, Sweden

William C. MARTIN, USA

François ROSTAS, France

(94) Vice President (2000-2003)

(94) Vice President (1994-1997)

Peter L. SMITH, USA

President (1997-2000)

(91) Vice President (1997-2000)

President (2000-03) 
New Members:

Saul J. ADELMAN, USA

Emile BIEMONT, Belgium

Steve FEDERMAN, USA

Jim LAWLER, USA

Michael MICKELSON, USA

Donald MORTON, Canada

Tanya RYABCHIKOVA, Russia

Chantal STEHLE, France

\section{Outgoing Members:}

Nicolas GREVESSE, Belgium

Uffe Grå JØRGENSEN, Denmark

Helen MASON, UK

William H. PARKINGSON, USA

W.-Ü.L. TCHANG-BRILLET, France
Secretary (2000-2003)

(85) President (1994-1997)

After the election, Peter Smith chaired the meeting.

After some discussion, the Commission voted to have two new Working Groups: (i), optical properties of solids, including matrix work, and (ii), gas phase reactions. The President will confer with the Organizing Committee to prepare statements of purpose for the new Working Groups and to identify possible Chairs and Co-Chairs.

\section{Working Groups}

1. Atomic Spectra \& Wavelengths

2. Atomic Transition Probabilities

3. Collision Processes

4. Line Broadening

5. Molecular Structure

6. Molecular Reactions on Solid Surfaces

7. Optical Properties of Solids

8. Gas Phase Reactions
Chair

S. JOHANSSON
W.L. WIESE
D. R. SCHULTZ
C. STEHLE
E. Van DISHOECK
W. SCHUTTE
tbd
tbd

\section{Co-Chair}

\author{
G. NAVE \\ J.R. FUHR \\ P.C. STANCIL \\ G. PEACH \\ J.H. BLACK \\ L. d'HENDECOURT \\ tbd \\ tbd
}

To better advertise future Commission reports, the officers will send announcements to newsletters of professional astronomical societies.

The President has been asked by the Executive Committee to update the Commission membership list. He and the Secretary will send letters to all members. They will also be asked to suggest new members and consultants as well as to propose topics for possible future symposia. Smith suggested we consider atomic data for $\mathrm{x}$-ray astronomy; others suggested photo-ionization modeling. Johansson suggested that whatever we sponsor it should cover several wavelength regions.

Smith on behalf of all the members of Commission 14 thanked Rostas for his leadership during the past three years and especially for his work in organizing the very successful Joint Discussion.

The new Commission email address will be com14_iau@adelvx.citadel.edu

Saul J. Adelman

Secretary of the Commission 